\title{
Ecological Based Natural Gas Production in Polar Regions of Russia
}

\author{
Anatoly K. Arabsky ${ }^{*}$ \\ Gazprom Dobycha Yamburg, LLC, N-Urengoy, YANAO Region, Russia
}

\begin{abstract}
This paper shows that in the polar areas with severe climate conditions the Environmental Policy must be stated on the Gazprom Dobycha Yamburg Company's standpoints of sustainable development on both the environment protection and social accountability principles implementation. It gives basis for short-term and mid-term goal-oriented planning of the Company's performance in this sphere. The Environmental Policy is subject to regular revision, update and improvement, following any alterations in the environmental laws of the Russian Federation and the Yamalo-Nenets Autonomous Okrug as well as any changes in development priorities and industrial welfare of the Company as Gazprom JSC subsidiary
\end{abstract}

Keywords: Polar Regions, sustainable gas production development, Gazprom Dobycha Yamburg, ecological basements.

\section{INTRODUCTION}

Gazprom Dobycha Yamburg LLC is a wholly owned subsidiary of OAO Gazprom (Russian Gas Encyclopedia, 2004; http://www.yamburg.ru). It is in this area that the first large-scale construction of processing facilities was implemented in the polar region using large pre-assembled units of up to 420 tons. The major activities of the Company cover gas and gas condensate production and processing to prepare it for transmission; geologic survey; new gas condensate and oil fields pre-development and development.

Altogether, in the company "Gazprom Dobycha Yamburg, LLC" there 2000 gas production wells, 19 centers for gas ptetreatment for transport, 15 gas compressor stations and more than $2000 \mathrm{~km}$ of inter-connected gas pipelines (Fig. 1- 4).

The share of Gazprom Dobycha Yamburg in the total gas production volume of Gazprom is over $40 \%$, i.e. more than $31 \%$ of all Russia's gas production. The annual production rate exceeds $200 \mathrm{bcm}$ of gas and 1.5 million tons of gas condensate. The Company holds licenses for the development of five fields located in the Yamalo-Nenets Autonomous Okrug: the Yamburgskoye, Zapolyarnoye, Tazovskoye, SeveroParusovoye and Yuzhno-Parusovoye fields (the last three fields are on the verge of development). In 2001, the Company commissioned the world's largest gas processing facility with a project capacity of $35 \mathrm{bcm}$ and the first gas from the Zapolyarnoye Field was delivered to the country's trunk pipeline. Field commissioning in 2001 made it possible to halt gas production decline in Russia. The Company possesses $15 \%$ of Russia's proved gas reserves and $52 \%$ of the operated fields in the north of the Tyumen Oblast.

*Address correspondence to this author at the Gazprom Dobycha Yamburg, LLC: Dr (tech) Anatoly K. Arabsky, Deputy Chief Engineer, Gazprom Dobycha Yamburg, LLC, N-Urengoy, YANAO Region, 629306 Russia; Tel/Fax: +734494966015; E-mail: A.Arabsky@ygd.gazprom.ru
In the short term it intends to develop the Neokomsk Deposits of the Zapolyarnoye Field, whereas the medium-term development will have two directions: to the west towards the fields located on the $\mathrm{Ob}$ and Taz Bays shelf (the SeveroKamennomysskoye and Kamennomysskoye-Sea fields) and to the north towards the fields on the Gydansk Peninsula. This will maintain the medium-term annual gas production at the level of at least $200 \mathrm{bcm}$.

\section{NATURE AND CLIMATE IN GAS FIELD AREAS}

Polar conditions determine all the features of gas production and accordingly one should start with the description of nature and climate in gas field areas (Bashkin et al. 2013).

Oil and gas condensate fields developed by Gazprom Dobycha Yamburg LLC (the Severo-Parusovoye, YuzhnoParusovoye, Yamburgskoye, Tazovskoye and Zapolyarnoye fields) are located on the Taz Peninsula, on the interfluve of Pur and Taz rivers in the West Siberian Plain (Fig. 5).

In terms of physical and geographical zoning of particular interest is the Taz Province comprising the peninsula of the same name located between the Ob and Taz Bay. The province forming part of tundra plain belt is a pooled dissected plain, which turns into a poorly dissected predominantly waterlogged area as it spreads southwards (Physiographic Regionalization 1973). Landscapes of the Taz Province are common to the middle (typical) tundra and southern tundra subzones of the plain belt. The middle tundra subzone is not only inhabited by moss and lichen associations, but widely developed willow plant formations confined to smooth slopes of valleys and interfluves. Gulf coasts and big rivers valleys are abundant in sedge-hypnum (moss) bogs while narrow slips of meadows commonly occur along the river banks. Willow grass and moss cenoses are most typical of watershed areas vegetation in this subzone. 


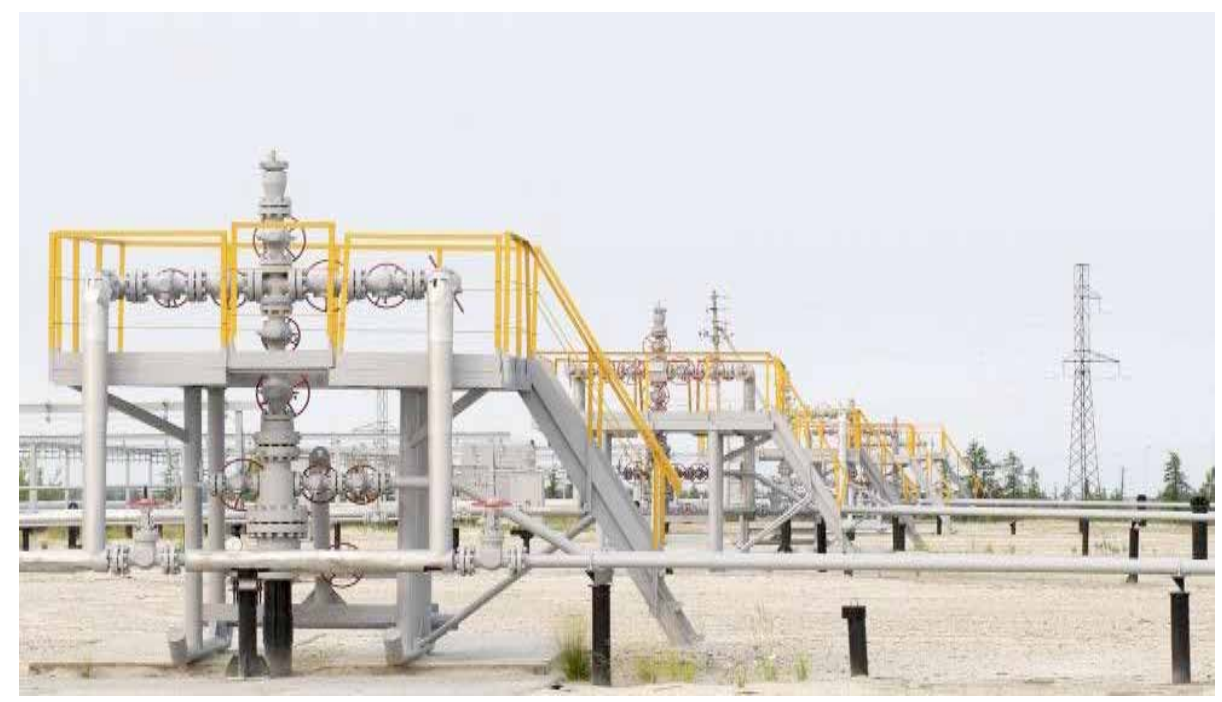

Fig. (1). Gas production well.

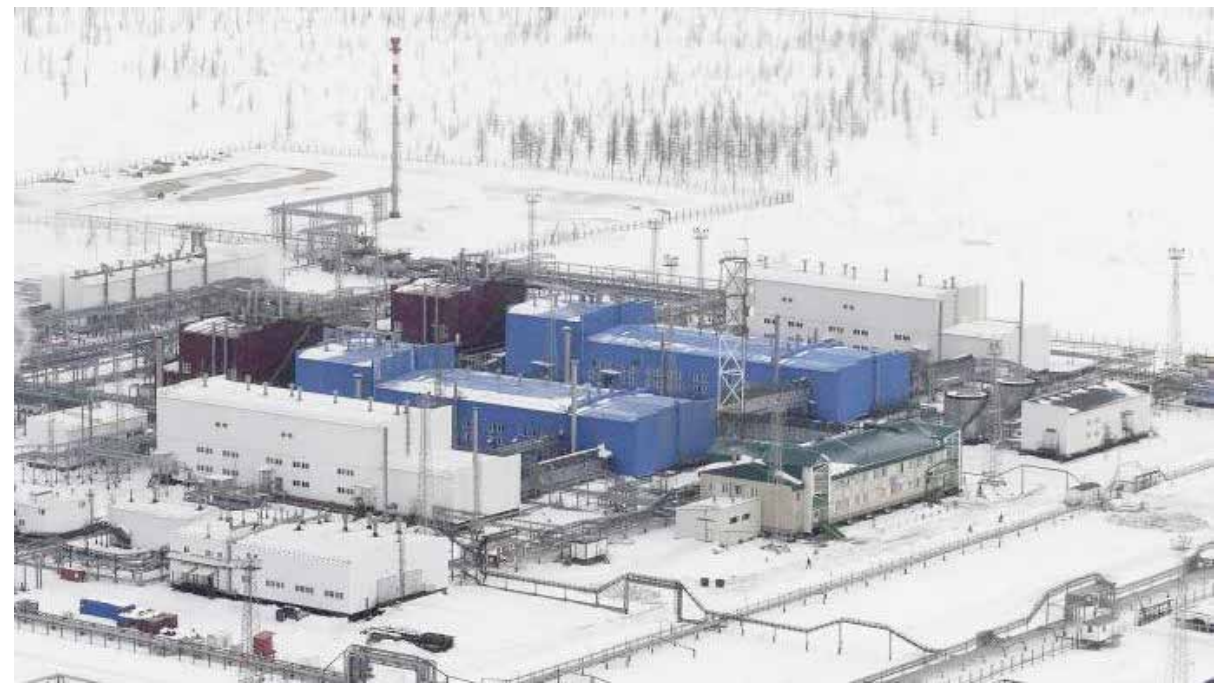

Fig. (2). Center for complex gas pretreatment for pipeline transport.

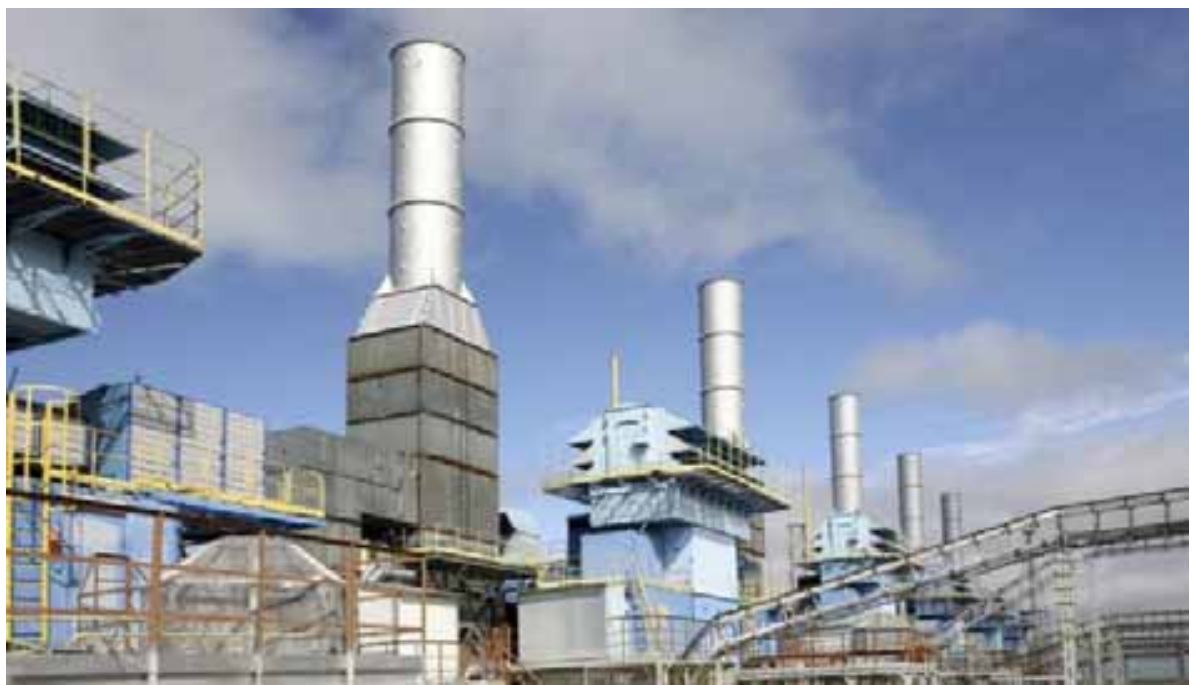

Fig. (3). Gas compressor station. 


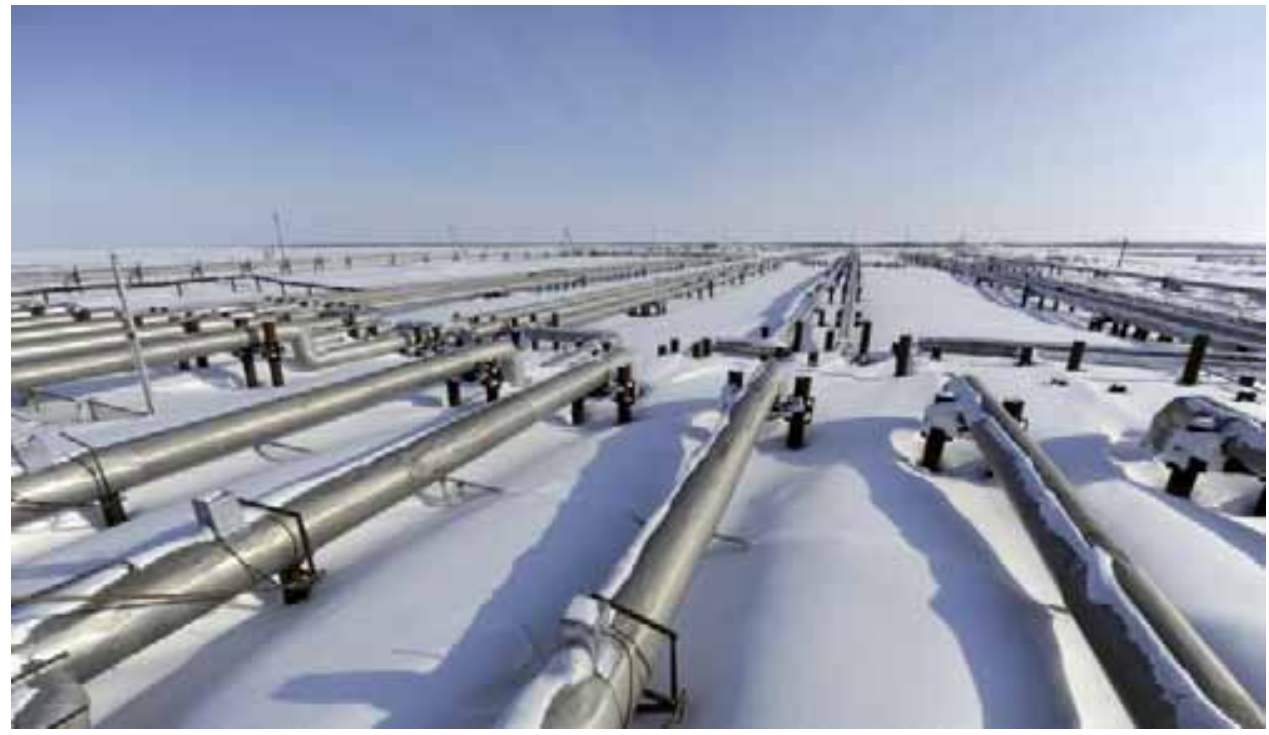

Fig. (4). Inter-connected gas pipelines.

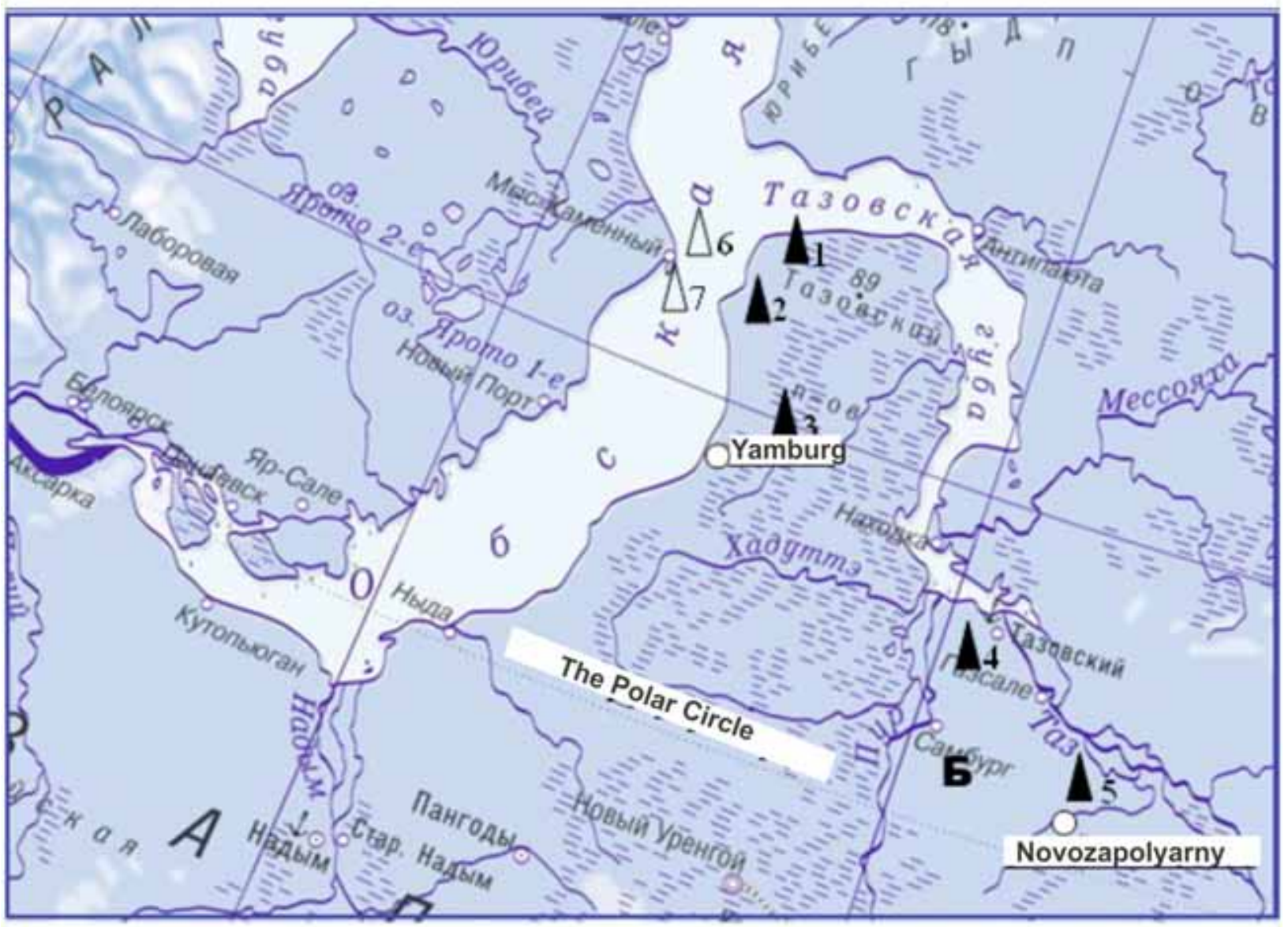

Fig. (5). Map of oil and gas condensate fields.

$\Delta$ - potential gas fields, $\boldsymbol{\Lambda}$ - fields under development or on the wake of development,

Б - the interfluve of Pur and Taz rivers;

- the Severo-Parusovoye Field; 2. - the Yuzhno-Parusovoye Field; 3. - the Yamburgskoye Field; 4. - the Tazovskoye Field; 5. - the Zapolyarnoye Field; 6. - the Severo-Kamennomysskoye Field; 7. - the Kamennomysskoye-Sea Field. 


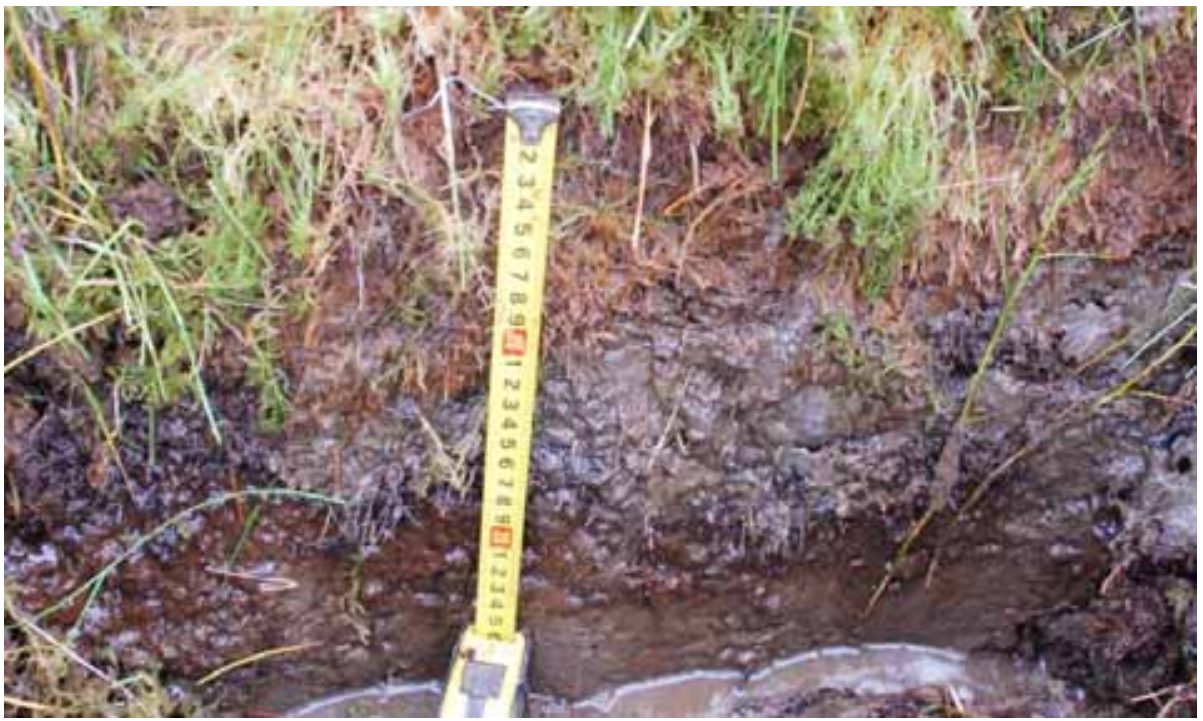

Fig. (6). Profile of typical tundra illuvio-humic gleyic soil.

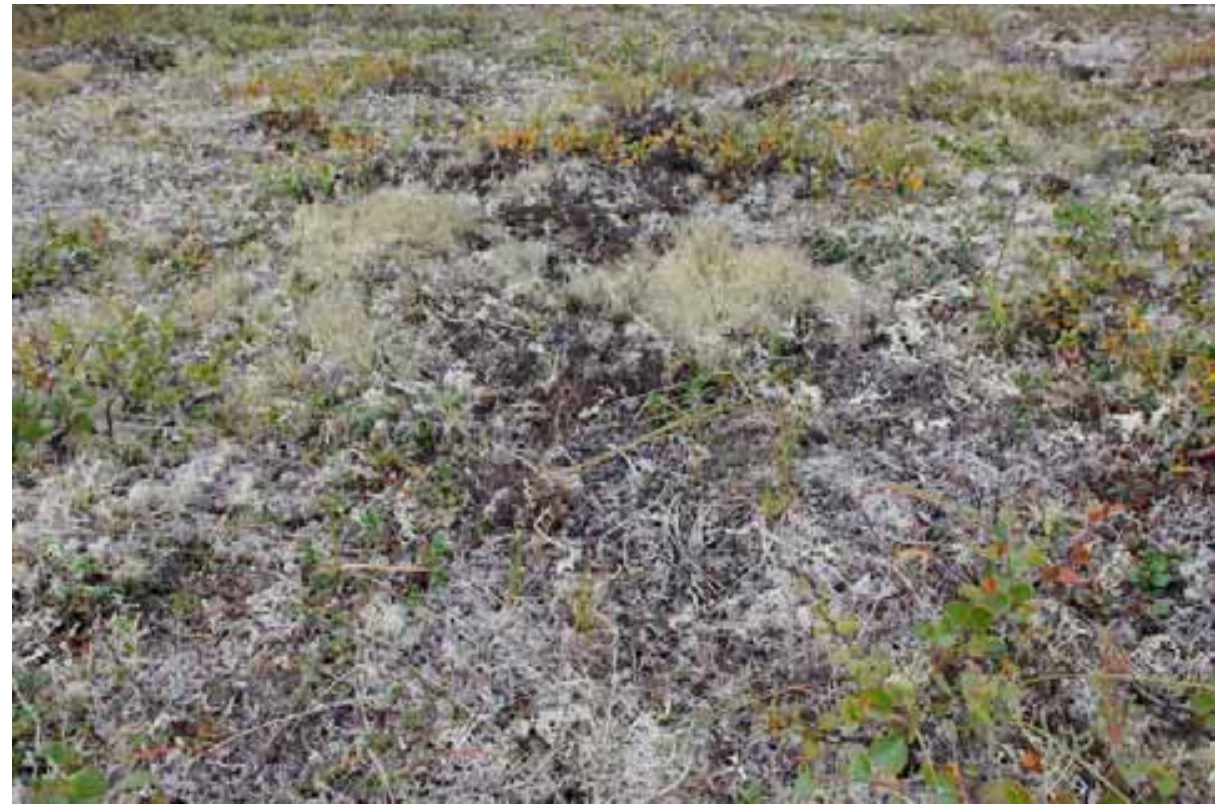

Fig. (7). Tunda ecosystem - cottongrass-moss-lichen hummocky marshes.

The outstanding features of middle-tundra subzone are tundra gley soils formed on loamy substrate under mossherb-mountain avens (dicotyledonous) vegetation. The soils have a poorly differentiated profile with the depth of $\mathrm{A}_{0} \mathrm{~A}$ horizon of $5-7 \mathrm{~cm}$. The soil stratum is evenly gleyed and the soil itself is neutral. Permafrost starts at the depth of $80 \mathrm{~cm}$. Arenaceous rocks of laida (meadow bogs) and terraces under moss-grass-willow and herb-moss vegetation create favourable conditions for the development of an autonomous complex of tundra raw residual illuvio-humic gleyic soils, spots of polygons bearing tundra illuvio-humic, at times podzolized soils of microdepressions. The soils have poor profile differentiation and shallow depth with sands laying at a depth of $30 \mathrm{~cm}$ and the permafrost laying at a depth of $1 \mathrm{~m}$ (Fig. 6).

In the southern tundra subzone flat interfluvial spaces are filled with frost mound bogs or hillock bogs with frost-thaw lake basins scattered in between. Lakeshores accommodate low sedge-sphagnum (moss) fens and flat mounds alternate with hollows, i.e. carrs between bog hillocks. As interfluvial plains become eroded at edges, their surface gets drier, thus affecting the vegetation cover, where appear cottongrassmoss or cottongrass-moss-lichen hummocky marshes. Grass sod of cottongrass hummocky marshes contains sphagnum and true mosses, which disappear if bogginess increases. The broad valleys are a place where willow-shrubs (up to 1.5-2.0 $\mathrm{m}$ high), yernik (dwarf birches) and alder forests along with a well-developed grass-herb stand grow. Frost mound and polygonal bogs have flat mounds separated by bypass hollows or cavities, i.e. tortuous boggy channels between frost peat mounds 1-3 m wide. Their vegetation cover includes ledum-averin-sphagnum-lichen associations, while hollow vegetation cover includes sedge-cottongrass associations (Fig. 7-8). The vegetation of mircoelevations in waterlogged tundra and frost mound and polygonal bogs mainly consists of various species of sphagnum and true mosses. 


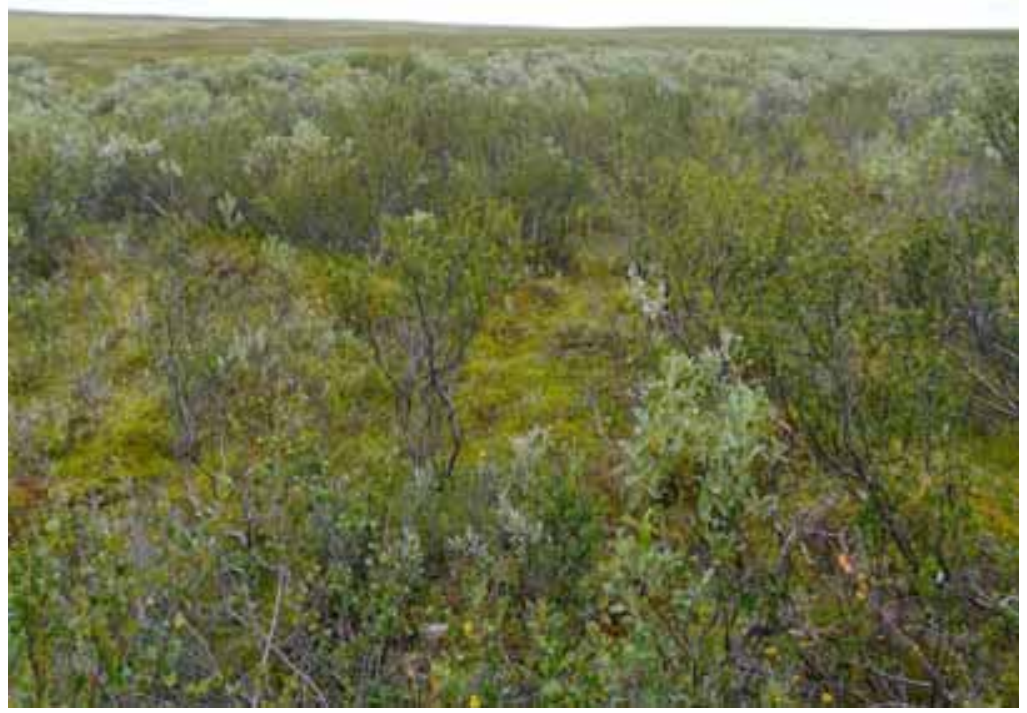

Fig. (8). Tundra ecosystem - willow-shrubs (up to 1.5-2.0 m high), yernik (dwarf birches) and alder forests along with a well-developed grass-herb stand

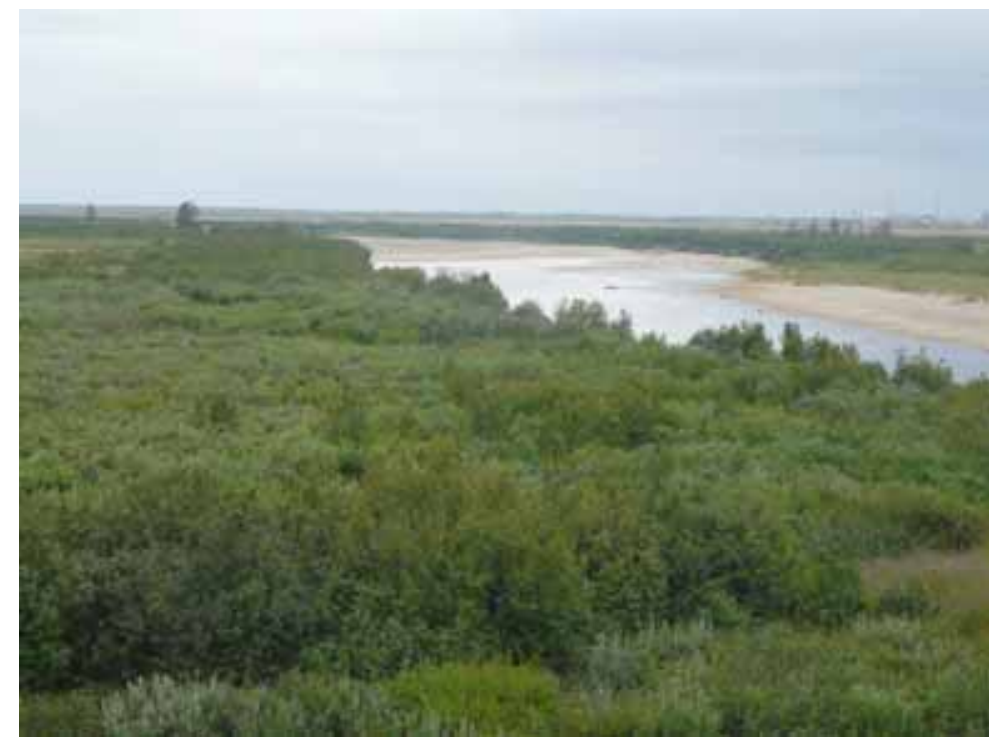

Fig. (9). Forested tundra ecosystem - Duschekia fruticosa in high-fluvial valley of river Sobeyacha. Back right - center for gas tretreatment of «Gazprom dobycha Yamburg, LLC

The southern tundra subzone widely accommodates an autonomous complex of tundra peat-illuvio-humic cryptopodzol soils, mounds of illuvio-humic or swampy-slimygley soils, hollows confined to sandy deposits. Peat-illuviohumic cryptopodzol soils have an irregular podzolic $\mathrm{A}_{2}$ horizon (its layer being up to $2 \mathrm{~cm}$ thick) underlying the $\mathrm{A}_{\mathrm{o}} \mathrm{A}$ horizon $(7 \mathrm{~cm}$ thick) and replaced beneath by gleyic sabulous $\mathrm{B}_{\mathrm{g}}$ horizon (10 $\mathrm{cm}$ thick), and the soils are acid. A complex of tundra peat-illuvio-gley soils and spots of microdepressions bearing tundra residual illuvio-gleyic soils shapes on light and medium-textured loams under spotted moss-lichenshrub association. It forms associations with swampy-tundra soils under shrub (yernik-moss) vegetation on ridge slopes.
Swampy-tundra soils characterized by increased humidity and thicker vegetation are widely spread in the subzone.

The Low Taz Province that encompasses the interfluve of Pur and Taz rivers forms part of tundra forest plain belt and represents a dissected pooled poorly waterlogged plain (Fig. 9). The interfluves here are formed by marine quaternary terraces $50-120 \mathrm{~cm}$ high. Broad valleys of Pur and Taz rivers with terraces above the developed floodplain cross the plain, while the rivers flow within sand banks and have sand cays. Tundra landscapes prevail in the province, whereas forest landscapes are confined mainly to the valleys of big rivers - the Pur and the Taz and sometimes are seen as small islands in the interfluvial plains. 


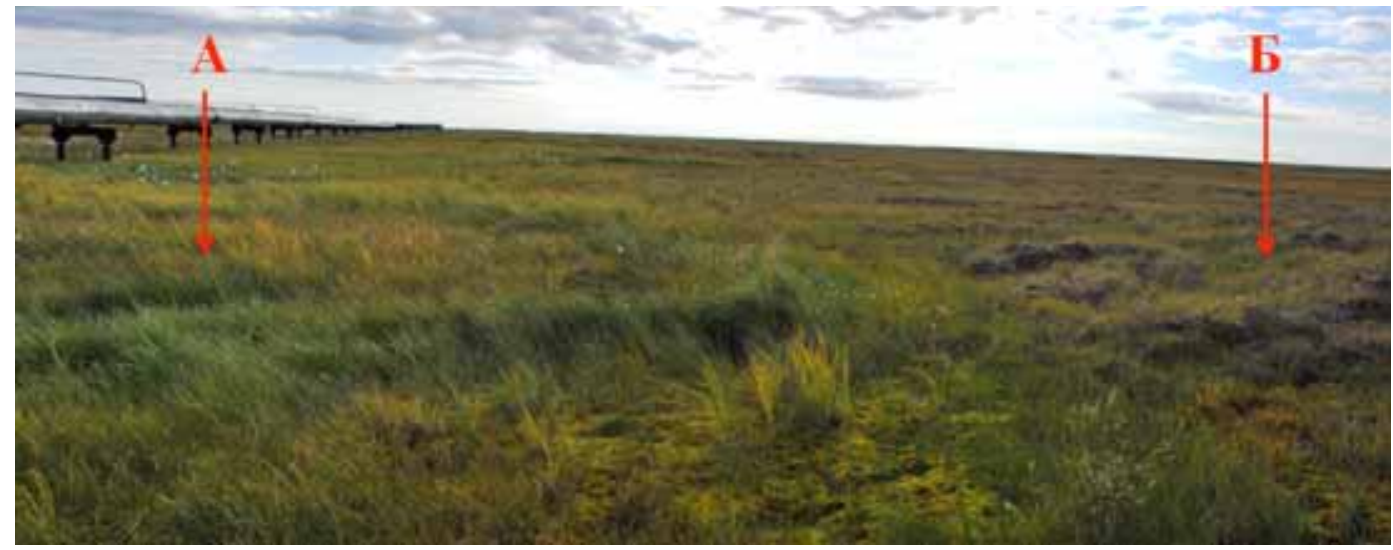

Fig. (10). Thermocarst bogs along gas pipeline (A) and nearby undisturbed background ecosysem (Б).

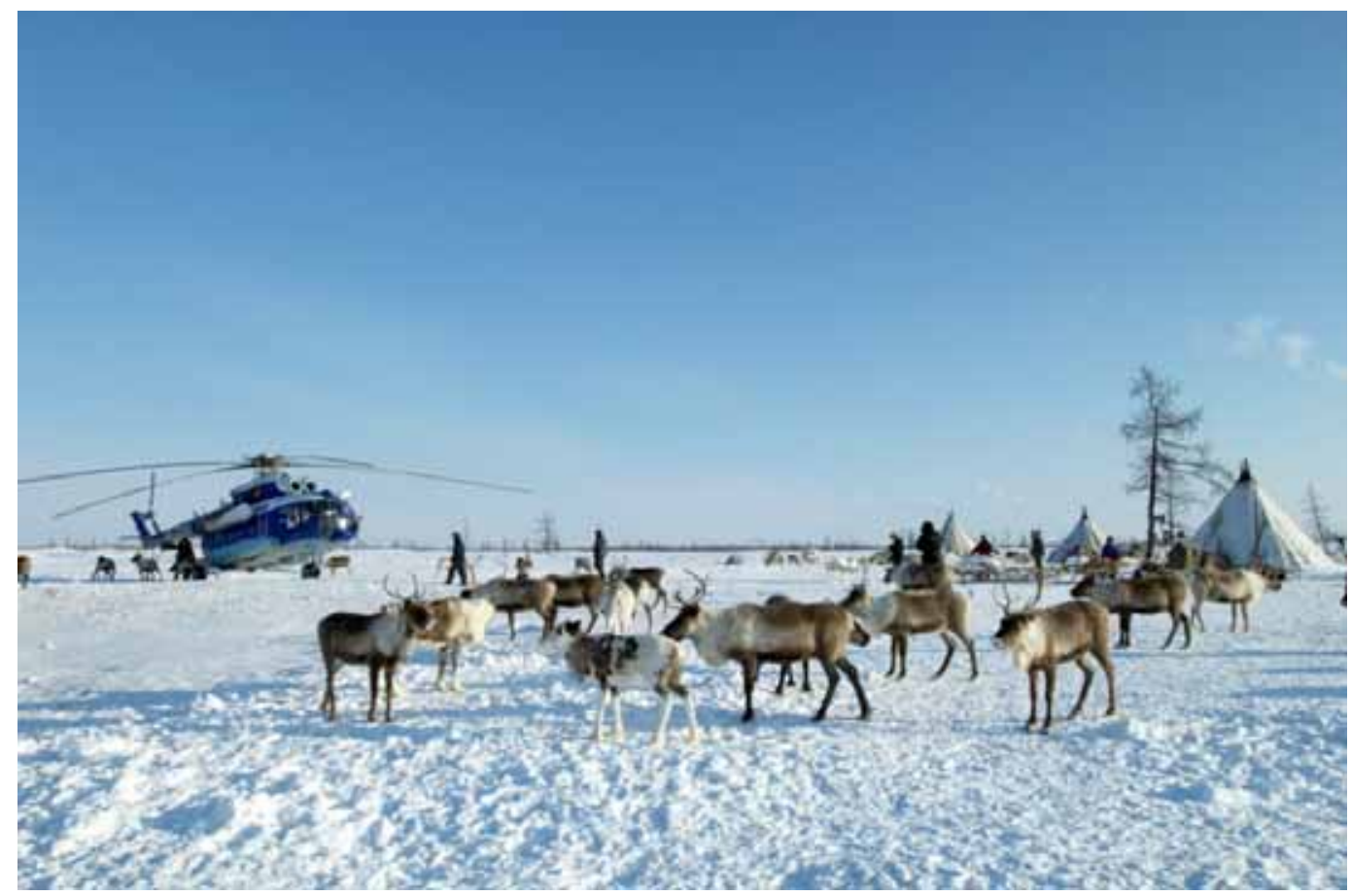

Fig. (11). Polar reindeer farm.

The part of forest tundra located to the east of the lower course of the Taz river, where the zone width reaches its maximum $(150-200 \mathrm{~km})$, is different in the north and in the south in terms of vegetation and landscapes. In the north frost mound bog complexes prevail, among which lakeside cavities and lowlands occupy a significant space (Fig. 10) while tree vegetation is represented by sporadic specimen or small groups of larches and birches. Forest associations occupy no more than a quarter of the total area and are confined to shrub-lichen tundras on tight sabulous soil bearing peat layer of about 7-8 cm thick (Bashkin, 2006).

\section{BIOLOGICAL RESOURCES AND GAS FIELDS LAND STOCK}

Economic activity of the indigenous population in the Far North mainly involves deer breeding, hunting and fishery with relevant relation to human health safety (Demidova $e t$ al. 2013). Deer breeding is the core industry developing here for centuries across the entire area (Bashkin, 2014). Almost the whole of the tundra appears to be deer pastures encompassing a wide range of plant associations - moss-lichen, meadow, bog, shrub vegetation, etc. According to feed composition and predominance, pastures fall into reindeer lichen (lichen), reindeer lichen-grassland, grass-shrub and grass pastures, while according to the period of use, they are divided into winter, summer and mixed pastures (Fig. 11). The best conditions for deer grazing are found in the middle tundra subzone with its fertile pastures of green fodder including various sorts of grass and shrub vegetation being available within the whole season of growth. Tundra of the Taz Peninsula appears to be good enough for summer pastures, while fodder conditions in the southern tundra subzone are sufficient for deer breeding in spring, summer and autumn. 


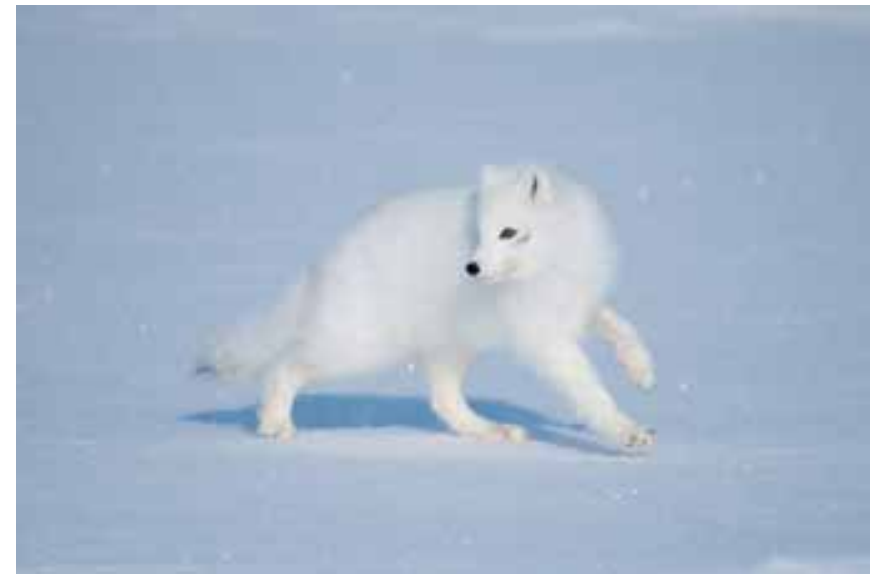

Fig. (12). Polar fox.

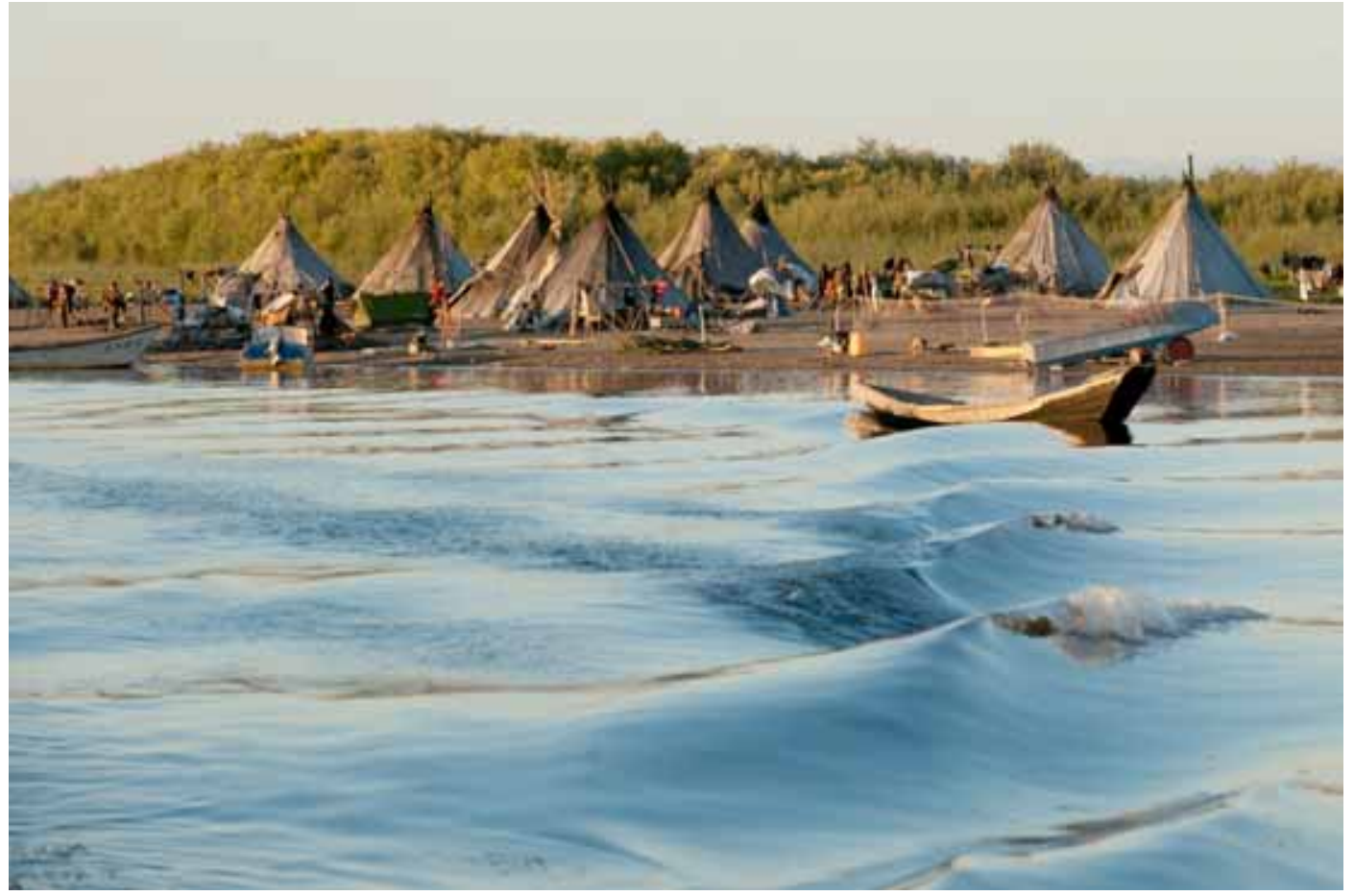

Fig. (13). Fishing village.

As for forest tundra, it mainly serves for winter deer pastures as snow here is less dense due to lack of windstorms, while grass and lichen fodder is good enough.

The local population of tundra mainly hunts polar foxes dispersed in a descending order from the arctic to the southern tundra. Of significant commercial interest is ptarmigan choosing the middle tundra subzone for nesting. The waterfowl includes geese, diving-ducks, etc. As for the forest tundra, polar fox is also of primary commercial value here and the locals hunt polar hare and ptarmigan as well (Fig. 12).

In the recent past the $\mathrm{Ob}$ and the Taz Bays were considered to be major fishing basins abundant in whitefish and high concentration of sturgeon, but ordinary fish (burbot) is in demand as well (Fig. 13). Lower reaches of the big rivers in the forest tundra and the southern end of the $\mathrm{Ob}$ Bay used to be the fishing grounds of whitefish, even more numerous than in tundra basins.

Nevertheless, the tundra zone is not really favorable for agriculture due to lack of heat (cumulative temperatures > $5^{\circ} \mathrm{C}$ are less than $1000^{\circ} \mathrm{C}$ ), low soil temperatures (no higher than $10-14^{\circ} \mathrm{C}$ at a depth of $10 \mathrm{~cm}$ ), high soil acidity and amorphy, poor agrophysical properties, meagerness of humus and nourishment, and low biological activity of soils. This is compounded by short vegetation season (60-70 days) and likely frosts in summer months. As for the warm season, there is no clearly defined period with mean daily temperature of $>10^{\circ} \mathrm{C}$. The forest tundra climate is severe having short and cool summers, the active season for vegetation is 


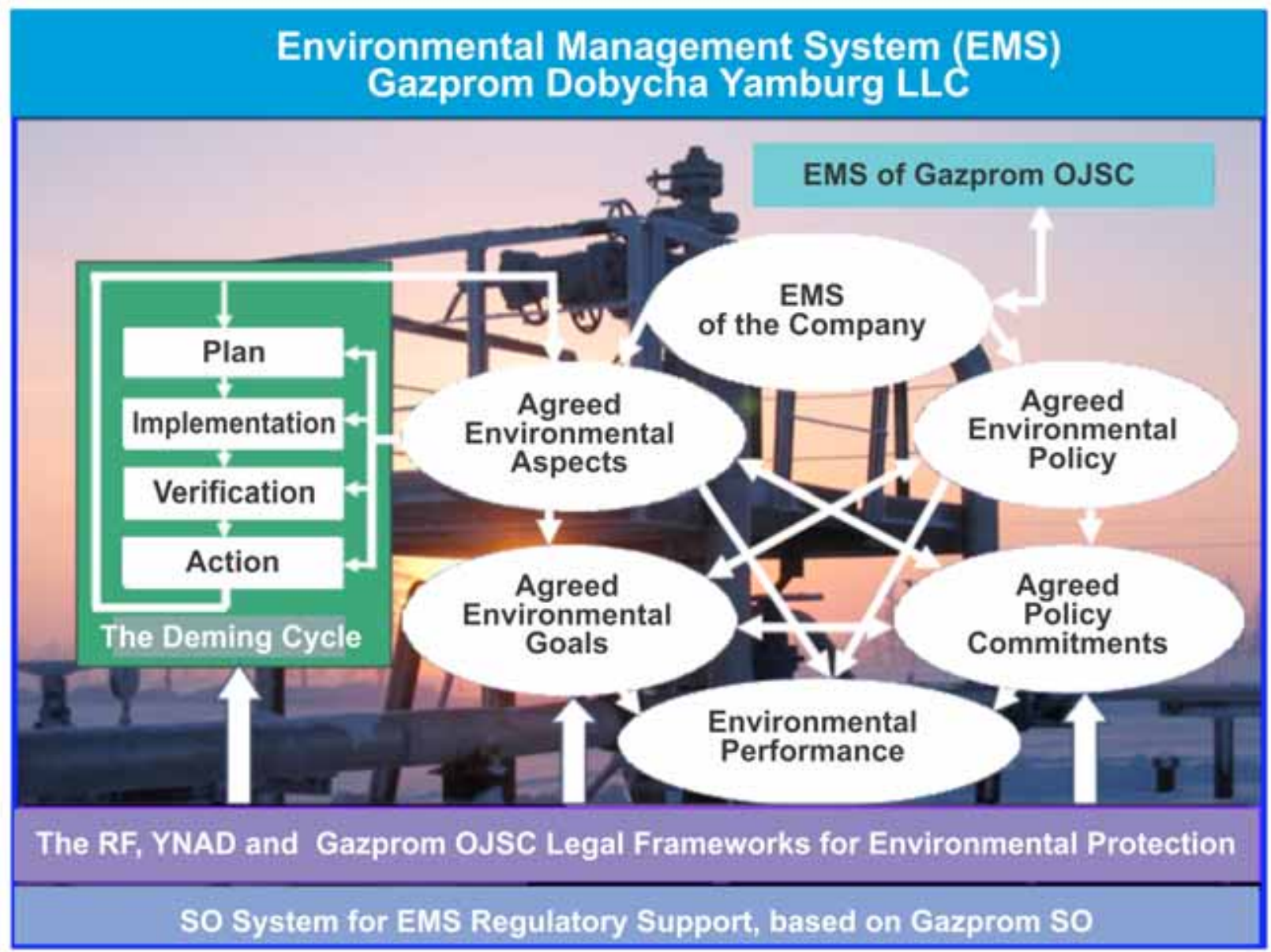

Fig. (14). Environmental management at Gazprom Dobycha Yamburg LLC.

Deming Cycle - a cycling process of decision-making and performance improvement;

YNAO - Yamalo-Nenets Autonomous Okrug; SO - standards of organizations.

no longer than 50 days with temperatures of $>10^{\circ} \mathrm{C}$ and $\mathrm{cu}-$ mulative temperatures for the period amounting to 700 $800^{\circ} \mathrm{C}$. The soils are residual, tight, waterlogged and poorly aerated, have high acidity and low temperatures, which in total results in low biological activity, since the plant nutrients in the soil are scarce.

Thus, the natural conditions of the gas fields location zones coupled with biological resources and soil reserves ensure sufficient ground for consistent policy on environmental protection, which was developed by Gazprom Dobycha Yamburg LLC and is going to be a subject of further discussion.

\section{ENVIRONMENTAL PROTECTION POLICY}

In consistency with a three-component sustainable development concept, Gazprom Dobycha Yamburg LLC strives to keep the balance between economic, social and environmental aspects of its activity [http://www.yamburg.ru]. The Company not only acts in compliance with the RF environmental laws, it also adheres by maximum to the international environmental standards. For this Gazprom Dobycha Yamburg LLC introduced its own Environmental Policy in 2009. To achieve its goals in the sphere of environmental protection, the Company implemented and maintained an efficient environmental management system (for environment protection supervision and management) based on the ISO 14001 guidelines, a generally accepted international standard (the Russian version of which is GOST R ISO 14001-2008). The latter defines the process of control and systematic improvement of the companies' ecological performance in the sphere of environmental protection. A systemic approach to environment protection supervision and management based on the guidelines of the standard is aimed at least to ensure a balance between gas production profitability and mitigation of adverse impact on the environment in preplanned technological cycles of production and preparation to further transmission of gas or gas condensate. The structure of the Company's environmental management system (EMS) and its interaction with the Gazprom JSC Environmental Management System and the laws of the Russian Federation and the Yamalo-Nenets Autonomous Okrug is shown in Fig. (14).

Following the key provisions of the Environmental Policy approved by the Decree No.45 of JSC Gazprom Board of Directors, on September 25, 2008, Gazprom Dobycha Yamburg LLC has worked out and adopted its own Environmental Policy. And at present the Company is guided by this policy. At the same time it strives to ensure reliable performance of its hydrocarbon production complex, rational natural resources utilization and preservation of favorable environ- 
ment on its licensed sites in the Far North. Fundamental principles of the Company's Environmental Policy, which is consistent with the RF Environmental Doctrine and the RF Concept of the country's transition to sustainable development, as well as generally recognized principles of social accountability, which are the following:

a) adverse impact mitigation and environment preservation in the production zones of the Company;

b) enhancement of natural and energy resources utilization efficiency;

c) efficient management of environment protection activity on the basis of national and international standards;

d) ensuring industrial and environmental safety at the stage of natural gas and gas condensate production facilities operation;

To implement these principles the Company is committed to:

1 act in accordance with the RF environmental laws, national standards, industry regulations and rules that apply to the environmental aspects of the Company's activity;

2 apply advanced administrative and technical methods and enhance environmental management system performance to mitigate the effect on the environment and ensure rational utilization of natural resources;

3 improve energy efficiency of production processes;

4 mitigate the effect on the environment by means of technological process optimization, production systems modernization and risk of accidents mitigation;

5 ensure compliance with the requirements of industrial and environmental safety, occupational safety and health (HSE) at the stage of the Company's project sites operation;

6 give priority to apply such equipment and technologies that have a minimum effect on the environment and lowest resource consumption;

7 prevent environmental pollution through preventive actions intended to avert possible adverse impact on the environmental;

8 involve all the Company's departments into activities to mitigate geo-environmental risks, improve the environmental management system and performance indicators in the sphere of environment protection;

9 take part in ensuring environmental safety of the areas accommodating the Company's production facilities;

10 ensure access for the general public to the environmental information on the Company's production activities and guarantee transparency of its environment protection activity and decision-making;
11 constantly improve administration and management of the Company's environment protection activity (environmental management system performance);

12 respect the interests and rights of the indigenous people of the North, for traditional way of life and habitat preservation;

13 carry out continuous training and develop vocational competence of the employees from all the Company's departments in the sphere of environment protection;

14 bring the key provisions of the environmental policy to the notice of all the Company's employees and the parties concerned, including suppliers and contractors.

\section{CONCLUSION}

The Environmental Policy states the Company's standpoint on the environment protection and sustainable development and social accountability principles implementation, gives basis for short-term and mid-term goal-oriented planning of the Company's performance in this sphere. The Environmental Policy is subject to regular revision, update and improvement, following any alterations in the environmental laws of the Russian Federation and the Yamalo-Nenets Autonomous Okrug as well as any changes in development priorities and industrial welfare of the Company as Gazprom JSC subsidiary.

\section{CONFLICT OF INTEREST}

The author confirms that this article content has no conflicts of interest.

\section{ACKNOWLEDGEMENTS}

The author expresses his deep appreciation and gratitude to Dr. O. Makluk, head of environmental protection department of Gazprom Dobycha Yamburg LLC, for helpful discussion and useful support.

\section{REFERENCES}

Bashkin, VN (2006) Modern Biogeochemistry, 2d edition, Springer, Dordrecht.

Bashkin, VN, Arno, OB, Arabsky, AK, Barsukov, AV, Priputina, IV \& Galiulin, RV (2013) Retrospective and Prognosis of Geoecological Situation in the Gas-Condensate Fields of the Polar Regions, Gazprom VNIIGAZ, Moscow.

Bashkin, VN (2014) Biogeochemistry of Polar Ecosystems in the Impacted Zones of Gas Industry, Gazprom VNIIGAZ, Moscow.

Demidova, NS, Bochkov, AV \& Bashkin, VN (2012) Mathematical Modeling of Transport Processes in the Systems of Surviving and Human Protection in the Extreme Conditions of the Environment, Gazprom VNIIGAZ, Moscow.

Russian Gas Encyclopedia (2004), Great Russian Encyclopedia, Moscow. http://www.yamburg.ru 